\title{
Proximate, Mineral Contents and Physicochemical Properties of Chrysophyllum Albidum (African Star Apple) Kernel Flour and Oil
}

\author{
1*AUDU, SS; ${ }^{2}$ BEETSEH, CI; ${ }^{1}$ EDWARD-EKPU, DU; ${ }^{1}$ EWUGA, AA
}

\author{
IDepartment of Chemistry, Nasarawa State University, Keffi, Nigeria \\ ${ }^{2}$ Department of Chemistry, Federal University of Agriculture, Markudi, Nigeria \\ *Corresponding Author Email: saratusteve1@gmail.com
}

\begin{abstract}
The flour and oil of the kernel of African Star Apple (Chrysophyllum Albidum Linn.) sourced from Maraba Gurku township of Nasarawa state was analysed to determine their potentials for industrial and human consumption. Standards methods were used to determine the proximate and mineral contents of the flour and physicochemical properties of the oil. The results obtained from the Proximate Analysis shows the kernel has a moisture content of $10.06 \pm 0.08 \%$, Ash content of $2.72 \pm 007 \%$, Crude lipid of $13.31 \pm 008 \%$, Crude Protein of $7.92 \pm 0.00 \%$, Crude Fibre of $1.59 \pm 0.00 \%$ and Carbohydrate of $65.41 \pm 0.05 \%$. This suggests that the flour can be a used as an alternative to cereals in compounding animal feed. The results from the Mineral Analysis showed the kernel has $0.01 \mathrm{mg} / \mathrm{g}$ of copper, 0.01 $\mathrm{mg} / \mathrm{g}$ of Iron, $37.50 \mathrm{mg} / \mathrm{g}$ of phosphorus, $57.37 \mathrm{mg} / \mathrm{g}$ of calcium and $0.44 \mathrm{mg} / \mathrm{g}$ magnesium. The Calcium-Potassium Ratio indicates the flour is a good source of calcium for bone formation. The Physicochemical analysis showed the oil has an Acid Value of $33.12 \pm 0.25 \mathrm{mgKOH} / \mathrm{g}$, a Saponification Value of $184.90 \pm 0.29 \mathrm{mgKOH} / \mathrm{g}$, an Iodine Value of $60.05 \pm 0.02$ $\mathrm{mgKOH} / \mathrm{g}$, a Free Fatty Acid Value of $16.05 \pm 0.14 \mathrm{mgKOH} / \mathrm{g}$, Peroxide Value of $2.10 \pm 0.10 \mathrm{~m} \mathrm{Eq} / \mathrm{kg}$, Moisture of $3.36 \pm 0.08 \%$, Unsaponifiable Matter of $5.26 \pm 0.05 \mathrm{~g} / \mathrm{kg}$ and an Ester Value of $151.78 \pm 0.15 \mathrm{mgKOH} / \mathrm{g}$. The quality of the kernel oil falls below the standard for edible oil but the oil may be useful in the paint and cosmetic industry.
\end{abstract}

DOI: $\underline{\text { https://dx.doi.org/10.4314/jasem.v23i7.9 }}$

Copyright: Copyright (C) 2019 Audu et al. This is an open access article distributed under the Creative Commons Attribution License (CCL), which permits unrestricted use, distribution, and reproduction in any medium, provided the original work is properly cited.

Dates: Received: 03 May 2019; Revised: 01 June 2019; Accepted 04 July 2019

Keywords: Chrysophyllum Albidum, Kernel, Oil, Flour

Seeds of plants are normally known to be a good source of food for animals, including humans because they contain many nutrients. Plant seeds from soybeans, groundnut, corn, cotton, sunflower palm nuts etc. have been sources of food, cooking oil and industrial oil since ancient times. Most of the foods consumed by humans such as cereals, legumes and nuts are seed-based. Seeds are often rich in oil and unsaturated fats are considered as healthy however not all seeds are edible. As the demand for edible vegetable oil and vegetable oil for industrial uses increases, there have been search for alternative and cheaper seeds for these purposes. Seed from the African star apple (Chrysophyllum Albidum Linn.) is been investigated as a potential source of nutritional oils, industrial raw materials and nutraceuticals in this study. The plant commonly known as "Agbalumo" (Yoruba) or "Udala" (Igbo) in local languages of Nigeria is classified as a wild plant and often grows to a height of about $36.5 \mathrm{~m}$ (Bada, 1997). C. Albidum is a forest tree species belonging to the Sapotaceae family and is naturally found in many tropical counties of Africa such as Nigeria, Uganda, Niger, Cameroon and Cote d'Ivoire (Bada, 1997). C. Albidum fruit is a berry orange to yellow in colour, about $6 \mathrm{~cm}$ in length and $5 \mathrm{~cm}$ in diameter when ripe. The fruit usually contains $3-5$ dark coffee-coloured hard shiny ellipsoid seeds that are about $2.8 \mathrm{~cm}$ long and $1.2 \mathrm{~cm}$ wide. The seed contains a white coloured kernel. Several studies have been done on the plant but most have been on the edible parts especially the pulp. The fleshy pulp of the fruit of C. Albidum which is commonly eaten as snacks has been attributed numerous health benefits such as vitamins $(C, B$ \& E) and Iron (Adepoju and Adenij, 2012; Oguntoyinbo et al., 2015; Adebayo, 2012; Bada, 1997). Adubiaro and Olaleye (2016) reported that the kernel of the seed has high level of fat and carbohydrate. Azor et al. (2017) reported that though the kernel has high carbohydrate which is a source of energy, it contains high levels of anti-nutritional or toxic factors. Ajayi and Ifedi (2015) reported that the flour of $C$. Albidum kernel could be a good source of potassium, magnesium and calcium, and has a higher quantity of mineral when compared to those reported for some African oil bean seeds in studies. In recent time studies have been done on the kernel as a source of domestic and industrial oil and there have been varying reports. However, the kernel of the seed has been reported to be a viable source of oil for several domestic and industrial purposes in

*Corresponding Author Email: saratusteve1@gmail.com 
Nigeria going by its oil yield (Adebayo, 2012; Chukwumalume et al., 2010). Less research has been done on the kernel of $C$. Albidum seed compared to the pulp and peel of the fruit. The seed of the fruit if not used for local games are usually thrown away as waste which can become an environmental nuisance. In the context of creating wealth from environment waste, this study is aimed at assess the kernel of C. Albidum seed as viable source of vegetable and industrial oil, and therefor add to the body of knowledge on the potential of the seed.

\section{MATERIALS AND METHODS}

Procurement and processing of seeds: C. Albidum seeds were bought from Orange market within the vicinity of Maraba Gurku township of Nasarawa state. The shells were separated manually from the kernel and dried for 5 days at ambient temperature. After the kernel were separated from the shell, they were redried in the oven for oil 180 minutes at $60^{\circ} \mathrm{C}$ to reduce moisture before grinding to flour to increase the surface area for oil extraction. The flour was further oven-dried to constant weight and then put aside for analysis.

Proximate Analysis of C. Albidum kernel flour: The moisture content was determined using AOAC method (2010). Ash content was determined using AOAC method (2010); the crude fibre and lipid contents were determined the methods described by Pearson (1976); the crude protein content was determined according to the method of AOAC (2010) using the Keldahl method; The method of James (1995) was used to determine the carbohydrate content of the sample.

Mineral Analysis of C. Albidum kernel flour: Sample for mineral analysis were prepared using the method described by AOAC (2010). Samples were digested at about $60^{\circ} \mathrm{C}$ in $10 \mathrm{~cm}^{3}$ of Nitric Acid and allowed to cool. The digested sample was filtered into a $100 \mathrm{ml}$ flask and marked up to deionized water. The metals were determined using Atomic Absorption Spectrophotometry (ICE 300 aa02134104 v1.30).

Oil Extraction: The oil was extracted from $640 \mathrm{~g}$ of the grounded sample and conducted in a Soxhlet extractor using $500 \mathrm{ml} \mathrm{n}$-hexane at a temperature $55-60{ }^{\circ} \mathrm{C}$ ) for eight hours. The oils sample obtained was transferred into a beaker and heated at $40{ }^{\circ} \mathrm{C}$ to evaporate the solvent collected alongside the oil was properly stored for subsequent physicochemical analysis.

Physicochemical Analysis of C. Albidum kernel oil: The analyses of Saponification Value, Unsaponifiable Matter, Peroxide Value, Acid Number/Value, Iodine
Value, Density (Specific Gravity), were carried out using the methods of AOAC (2010). Ester Value $(\mathrm{mgKOH} / \mathrm{g})=$ Saponification Value - Acid Number/Value \pm DSV of duplicate value. Free Fatty Acid value $(\mathrm{mgKOH} / \mathrm{g})=0.503 \times$ Acid Number/Value \pm DSV of duplicate value (Aremu et al., 2015).

\section{RESULTS AND DISCUSSION}

Proximate Composition of C. Albidum kernel flour: The result for the proximate analysis of $C$. Albidum kernel oil is presented in Table 1. The result shows the kernel have a moisture content that fall within the $7-$ $11 \%$ moisture content range of legumes reported by Arkroyed and Doughty (1964). This mean it can be stored as long as legumes before spoiling. The result for ash content, crude protein, carbohydrate content and crude lipid are similar to those reported $(2.32 \pm$ $0.02,8.14 \pm 0.13 \%, 63.94 \pm 0.12 \%$ and $12.82 \pm 0.04 \%$ respectively) by Ajayi and Ifedi (2015) for ash content, crude protein and crude lipid respectively in their study. The ash content gives the amount of mineral element and inorganic matter present in a food sample. Ash content observed is high when compared with ash value $(1.6 \%$ to $2.9 \%)$ of cereals as reviewed by Edward-Ekpu et al. (2016) but lower than 4.28 of Bambara nut as reported by Aremu et al. (2006). The crude fibre content result is $1.59 \pm 0.00 \%$. This is similar to the value $(1.50 \pm 0.07)$ reported by Damilola et al. (2016) and higher than the values (1.22 \pm 0.02 and $1.19 \pm 0.01 \%$ ) reported by Agbabiaka et al. (2013) for raw and fermented kernel. The crude fibre in the kernel appears to be less than that of cereal which ranges from $2.0-8.1 \%$. A total carbohydrate content was observed to be within the range $(48.6-81.6 \%)$ reported for cereals by Edward-Ekpu et al. (2016). This suggests that the kernel flour can be a useful as an alternative to cereals in compounding animal feed.

Table 1. Proximate composition of C. Albidum kernel flour

\begin{tabular}{ll}
\hline Parameter & Value \% \\
\hline Moisture content & $10.06 \pm 0.08$ \\
Ash content & $2.72 \pm 007$ \\
Crude lipid & $13.31 \pm 008$ \\
Crude protein & $7.92 \pm 0.00$ \\
Crude fibre & $1.59 \pm 0.00$ \\
Carbohydrate & $65.41 \pm 0.05$ \\
\hline \multicolumn{2}{c}{ $\pm D S$ of triplicate value }
\end{tabular}

Mineral Composition of C. Albidum kernel flour: The result from the mineral analysis of $C$. Albidum kernel flour is presented in Table 2. The kernel was found to be a good source of phosphorus $(37.50 \mathrm{mg} / \mathrm{g})$, calcium $(57.37 \mathrm{mg} / \mathrm{g})$ and magnesium $(0.44 \mathrm{mg} / \mathrm{g})$. The result showed that of the minerals tested for phosphorus and calcium were the most abundant. All the values observed for mineral content (copper, iron, phosphorus, calcium and magnesium) were higher 
than the values of these element reported by Agbabiaka et al. (2013) in their mineral analysis of both the raw and fermented kernel of the fruit. Copper by and iron, and a value of $0.44 \mathrm{mg} / \mathrm{g}$ for magnesium. However, Ajayi and Ifedi (2015) reported higher values for copper, iron and magnesium but lower values for phosphorus and calcium. The calcium content observed in this study is higher than those in cereals (Edward-Ekpu et al., 2016). It was so observed that the Calcium-Potassium Ratio (C:P Ratio) is greater than one (1) indicating that can serve as a good source of calcium for bone formation as a ratio is less than 0.5 is considered a poor source (Nieman et al., 1992). This is based on fact that diets rich in phosphorus may promote the loss of Calcium in the urine (Shills and Young, 1988). Cadmium was not detected in the kernel sample.

\begin{tabular}{ll} 
Table 2 Mineral composition $(\mathrm{mg} / \mathrm{g})$ of C. Albidum $\mathrm{kernel}$ \\
\cline { 2 - 2 } Parameter & Sample Concentration $(\mathbf{m g} / \mathbf{g})$ \\
\hline Copper & 0.01 \\
Iron & 0.01 \\
Phosphorus & 37.50 \\
Calcium & 57.37 \\
Magnesium & 0.44 \\
Cadmium & $\mathrm{ND}$ \\
\hline \multicolumn{3}{c}{} & $N D=$ Not Detected
\end{tabular}

Physiochemical properties of C. Albidum kernel oil: The result of the Physiochemical analysis of $\mathrm{C}$. Albidum kernel oil is presented in Table 3. The physiochemical properties of the oil extracted from the seed of C. Albidum were assessed to determine its qualities. As shown in the table 3, a Free Fatty Acid value of $16.05 \pm 0.14 \mathrm{mgKOH} / \mathrm{g}$ and an Acid value of $33.12 \pm 0.25 \mathrm{mgKOH} / \mathrm{g}$ was detected for oil. The values are higher than those $(4.50 \mathrm{mgKOH} / \mathrm{g}$ and 2.25 $\mathrm{mgKOH} / \mathrm{g}$ ) reported by Adebayo et al. (2012) for raw sample of $C$. Albidum oil and similar to the value reported by Aladekoyi et al. (2016) for the oil from fermented C. Albidum seed. The acid value of the oil was found to be higher than the Codex standard for virgin vegetable and the range recommended for cooking oil which is $0.00-3.00 \mathrm{mgKOH} / \mathrm{g}$ (Oderinde et al., 2009). According to Demian (1990), acid content (which is an index of free fatty acid content) shows the degree to which the glycerides in the oil has been decomposed due to enzymatic activity such as lipase action and other physical factors such as light and heat. The high acid value of the oil under investigation suggest that the oil susceptible to lipase activity, other hydrolytic action or oxidation and is not suitable for cooking. The saponification value $(184.90 \pm 0.29 \mathrm{mgKOH} / \mathrm{g})$ of the oil is less $199.50 \pm 0.29$ $\mathrm{mgKOH} / \mathrm{g}$ that reported by Aladekoyi et al. (2016) for the oil from fermented $C$. Albidum seed and similar to $180.92 \pm 0.02 \mathrm{mgKOH} / \mathrm{g}$ reported by Adebayo et al.
(2012) for raw sample of C. Albidum oil. Saponification value is an index of the average molecular mass of the fatty acids in an oil sample (Oladiji et al., 2010). A high saponification value indicates a high proportion of fatty acids of low molecular weight or short-chain acids required for the production of soap that is soluble soap (Akbar et al., 2009) and the thermal stabilization of poly vinyl chloride (PVC) (Mohammed and Hamza, 2008). The Saponification Value of the oil from this study was observed to be less than the standard Codex Alimentarius (2005) values range of $250-260 \mathrm{mg}$ $\mathrm{KOH} / \mathrm{g}$.

\begin{tabular}{ll} 
Table 3 Physiochemical properties of C. Albidum kernel oil \\
\hline Parameter & Value \\
\hline Acid Number/Value $(\mathrm{mgKOH} / \mathrm{g})$ & $33.12 \pm 0.25$ \\
Saponification Value $(\mathrm{mgKOH} / \mathrm{g})$ & $184.90 \pm 0.29$ \\
Iodine Value $(\mathrm{mgKOH} / \mathrm{g})$ & $60.05 \pm 0.02$ \\
Free Fatty Acid value $(\mathrm{mgKOH} / \mathrm{g})$ & $16.05 \pm 0.14$ \\
Peroxide Value $(\mathrm{m} \mathrm{Eq} / \mathrm{kg})$ & $2.10 \pm 0.10$ \\
Moisture $(\%)$ & $3.36 \pm 0.08$ \\
Unsaponifiable Matter $(\mathrm{g} / \mathrm{kg})$ & $5.26 \pm 0.05$ \\
Ester Value $(\mathrm{mgKOH} / \mathrm{g})$ & $151.78 \pm 0.15$ \\
\hline
\end{tabular}

The Peroxide Value of $2.10 \pm 0.10 \mathrm{~m} \mathrm{Eq} / \mathrm{kg}$ is higher than $1.80 \pm 0.28 \mathrm{mEq} / \mathrm{kg}$ and $1.51 \pm 0.42 \mathrm{~m} \mathrm{Eq} / \mathrm{kg}$ reported by Akubugwo et al. (2007) and Aladekoyi et al. (2016) respectively for raw oil from C. Albidum seed. All these values are far below the maximum acceptable value of $10 \mathrm{mEq} / \mathrm{kg}$ set by the Codex Alimentarius Commission (2015). Peroxide value is an index of rancidity. It is an indicator of the deterioration of lipids due to oxidation at the double bond of an unsaturated fatty acid which causes rancidity (Inekwe et al., 2012).

The Iodine Value $(60.05 \pm 0.02) \mathrm{mgKOH} / \mathrm{g}$ obtained for the oil sample is higher than $33.18 \pm 0.08 \mathrm{mgKOH} / \mathrm{g}$ reported by Audu et al. (2013) and lower than $7.1064 \pm 0.01 \mathrm{mgKOH} / \mathrm{g}$ report by Aladekoyi et al. (2016) for crude seed oil of C. Albidum. The value from the oil in this study is higher that the Codex Alimentarius (2005) Standard range 6.3-10.6 $\mathrm{mgKOH} / \mathrm{g}$. The iodine value is used to quantify the amount of double bonds in an oil which reflects its susceptibility to oxidation. The high iodine value observed from the test is an indication of the presence of high a fraction of unsaturated fatty acids in the seed oil of C. Albidum. The Unsaponifiable Matter value obtained was $5.26 \pm 0.05 \mathrm{~g} / \mathrm{kg}$ which lower than the standard value of $10 \mathrm{~g} / \mathrm{kg}$. The Unsaponifiable Matter is oily matter that cannot be converted into soap during saponification by alkali hydroxides. The Ester value of $\mathrm{mgKOH} / \mathrm{g} 151.78 \pm 0.15$ obtained in the study means $151.78 \pm 0.15 \mathrm{mg}$ of $\mathrm{KOH}$ required to hydrolyse the fatty acids present in the glyceride form in $1 \mathrm{~g}$ of oils 
or fat, indicting the actual amount of glyceride present in the sample of oil, which is saponafiable. High ester value indicates the presence of high amount of ester and low molecular weight fatty acid content (Belsare and Badne, 2007). The value observed for the oil of $C$. Albidum in this study is below the range of values $(169.18$ - $251.639 \mathrm{mgKOH} / \mathrm{g})$ reported for several edible oils such as groundnut oil, sesame oil, soybeans and cotton oil.

Conclusion: The study showed that C. Albidum kernel flour has a high carbohydrate content, good calciumpotassium content ratio and good level of nutrients that makes it an attractive and possible option for compounding animal feed. The quality of oil from the kernel falls below the standard for edible oil and good quality solid soap but the oil may be useful in the paint and cosmetic industry. The viability of the oil been used as a biodiesel should be further researched.

\section{REFERENCE}

Adebayo, SE; Orhevba, BA; Adeoye, PA; Musa, JJ; Fase, OJ (2012). Solvent Extraction and Characterization of Oil from African Star Apple (Chrysophyllum Albidum) Seeds. Acad. Res. Int. 3(2):178- 183.

Adepoju, OT; Adeniji, PO (2012). Nutrient composition and micronutrient potential of three wildly grown varieties of African star apple (Chrysophyllum Albidum) from Nigeria. Afri. J. Food Sci. 6 (12):344-351.

Adubiaro, HO; Olaleye, AA (2016). Proximate, Minerals and Fatty Acids Composition of African Star Apple Seed (Chrysophyllum Albidum). Proceedings of The 2016 Faculty of Science International Conference.

Agbabiaka, LA; Eke LO; Nwankwo, CF (2013). Nutrients and Phyto-Chemical Assay of African Star Apple Kernel (Chrysophyllum africanum) as Potential Feedstuff in Fish and Livestock Production. Brit. J. of Appl. Sci. \& Tech. 3(4):1215-1219.

Ajayi, IA; Ifedi, EN (2015). Chemical and Preliminary Toxicological Evaluation of Chrysophyllum Albidum Seed Flour in Dietary Formulation of Albino Rats. IOSR J. Env. Sci. Toxic. Food Tech. 9(6):59-67.

Akbar, E; Yaakob, Z; Kamarudin, SK; Ismail, M; Salimon, J (2009). Characteristic and composition of Jatropha Curcas oil seed from Malaysia and its potential as biodiesel feedstock. Euro. J. Sci. Res. 29:396-403.

Akubugwo, IE; Yusuf, D; Obiegunam, JE (2007). Physiochemical Studies on Oils from Five Nigerian Plant seeds. Pak. J. Nutr. 6:75-78

Aladekoyi, G; Shakpo, I.O; Omosuli, SV; Jide, AO (2016). The Effect of Fermentation on the Physiochemical and the Fatty Acid Composition of Oil of African Star Apple Endosperm (Chrysophyllum Albidum). Int. J. Sci. Res. Eng. Studies 3(1):49-62

AOAC (2010). Official Methods of Analysis. $18^{\text {th }}$ Ed., Rev. 3, Association of Official Analytical Chemists, Washington DC.

Aremu, MO; Ibrahim, H; Bamidele TO (2015). Physicochemical Characteristics of the Oil Extracted from Some Nigerian Plant Foods - A Review. Chem. Process Eng. Res. 32:222-228.

Aremu, MO; Olaofe, O; Akintayo, ET (2006). Chemical Composition and Physicochemical Characteristics of Two Varieties of Bambara Groundnut (Vigna subterrenea) Flours. J. Appl. Sci. 6:1900-1903.

Arkroyed, WR; Doughty, J (1964). Legumes in human Nutrition. Food and Agricultural Organisation Nutrition Studies Publication 19.

Audu, TOK; Aluyor, EO; Edualeona, S; Momoh, SS (2013). Extraction and Characterization of and Luffa cylindrical seed Oils. Petroleum Technology Journal: An Int. J. 3 (1):1-7.

Azor, A; Kolade, J; Adebisi, A; Sola-Ojo, F; Edoh, J; Ajide, S (2017). Utilization of African Star Apple (Chrysophyllum Albidum) Kernel Meal in Broiler Diets. J. Agri. Sci. 62(2):143-154.

Bada, SO (1997). Preliminary Information on the Ecology of Chrysophyllum albidun in West and Central Africa. In proceedings of National Workshop on the potential of the star apple in Nigeria pp. 16-25.

Belsare, GW; Badne, SG (2007). Study On PhysicoChemical Characterization of Edible Oils from Agencies of Buldhana District. Int. J. Res Pharm. Chem. 7(4):525-529.

CODEX Alimentarius Commission, 2005 Codex standard for named vegetable oils- 'Codex stan 
210-1999'. Food and Agricultural Organisation of the United Nations and the World Health Organisation.

Damilola, AO; Ugochukwu, BA; Oti, AA (2016). Comparative Evaluation of Chemical Profile of chrysophyllum Albidum Seed Cotyledon and Leaf. J. Med. Plants Studies 4(4):203-207

Demian, MJ (1990) Principles of Food Chemistry. 2nd Ed. Van Nostrond Reinhold International Company Limited, London, England, pp: 37-38.

Edward-Ekpu, DU; Audu, SS; Odiba, VA; Okopi. OS; Affiku, ML (2016). African Cereals and NonAfrican Cereals: A Comparative Review of Their Nutritional Composition. World J. Appl. Chem. $1(2): 30-37$

Inekwe, UV; Odey, MO; Gauje, B; Dakare, AM; Ugwumma, CD; Adegbe, ES (2012). Fatty Acid Composition and Physicochemical properties of Jatropha Curcus oils from Edo and Kaduna State of Nigeria and India. Annals Bio. Res. 3:48604864

James, CS (1995). Analytical Chemistry of Food. Champion and Hall, London, PP: 64-65.

Mohammed, MI; Hamza, ZU (2008). Physicochemical Properties of Oil Extracts from Sesamum Indicum
L. Seeds Grown in Jigawa State - Nigeria. J. Appl. Sci. Environ. Manage. June, 12(2) 99-101

Nieman, DC; Butterworth, DE; Nieman, CN (1992). Nutrition. Winc Brow Publishers. Dubugne, USA. Pp 237-312.

Oderinde, RA; Ajayi, IA; Adewuyi, A (2009). Characterisation of seed and seed oil of Hura crepitans and the Kinetic of Degradation of the oil during Heating. Electr. J. Environ. Agri. Food Chem. 8 (3):201- 208

Oguntoyinbo. OO; Abdus-Salaam RB; Bello WA; Ifesan BOT (2015). Evaluation of Phytochemical, antioxidant and antimicrobial properties of the extract from chrysophyllum Albidum (African Star Apple) leaf. J. Food Tech. Res. 2(1):1-10

Oladiji, AT; Yakubu, MT; Idoko, AS; Adeyemi, O; Silva, MO (2010). Studies on the Physicochemical Properties and Fatty Acid Composition of the Oil from Ripe Plantain Peel (Musa Paradisiaca). Afri. Scient. 11 (1):73-78

Pearson, DA (1976). Chemical Analysis of food ( $7^{\text {th }}$ Edition). Edinburgh, Churchill, Livingstone, Pp. 4222- 511.

Shills, ME; Young, VR (1988). Modern nutrition in health and disease. In: Nieman DC; Butterworth DE; Nieman CN (ed) Nutrition, Winc Brow Publishers. Dubugne, USA. Pp 276-282. 